\title{
Metabolism of the portal-drained viscera and liver
}

Book or Report Section

Accepted Version

Lindsay, D. B. and Reynolds, C. (2005) Metabolism of the portal-drained viscera and liver. In: Dykstra, J., Forbes, J. and France, J. (eds.) Quantitative Aspects of Ruminant Digestion and Metabolism, 2nd edition. CAB International, pp. 311-344. ISBN 9780851998145 Available at http://centaur.reading.ac.uk/90866/

It is advisable to refer to the publisher's version if you intend to cite from the work. See Guidance on citing.

Publisher: $\mathrm{CAB}$ International

All outputs in CentAUR are protected by Intellectual Property Rights law, including copyright law. Copyright and IPR is retained by the creators or other copyright holders. Terms and conditions for use of this material are defined in the End User Agreement. 


\section{www.reading.ac.uk/centaur}

\section{CentAUR}

Central Archive at the University of Reading

Reading's research outputs online 


\title{
12 Metabolism of the Portal-Drained Viscera And Liver
}

\author{
D.B. Lindsay ${ }^{1} \&$ C.K. Reynolds ${ }^{2}$ \\ ${ }^{1}$ School of Biological Sciences, University of Nottingham, Sutton Bonington Campus, \\ Loughborough, Leicestershire LE12 5RD, UK. ${ }^{2}$ The Ohio State University, Department of Animal \\ Sciences, 110 Animal Science Building, 2029 Fyffe Road, Columbus, OH 43210-1095 USA.
}

\section{INTRODUCTION}

Viscera whose blood supply drains into the portal vein include most of the alimentary tract, the spleen and the pancreas. In addition, mesenteric and omental fat depots, which can be substantial, contribute portal venous blood. Since it is the large expansion of the stomach that characterises ruminants, it is understandable that special attention is devoted to metabolism in this region. Many metabolic peculiarities of ruminants stem from this. Most blood flowing into the liver is portal and since the metabolism of the liver is linked with that of the gastrointestinal tract, some features of its metabolism are also included.

The chapter emphasises the quantification of nutrient and hormonal flows in the splanchnic region. Several techniques have been used to study ruminant metabolism. Among the most recent techniques available for use in intact animals is that of nuclear magnetic resonance (NMR) e.g. glycogen metabolism in human liver (Morris et al., 1994). However the high cost of equipment for this has rendered it unavailable for large animals such as sheep, goats and cattle. Thus only the arteriovenous (A-V) difference technique is considered here. This involves implantation (under general anaesthesia) of plastic catheters in an artery and in the mesenteric, portal and hepatic veins (see Fig. 12.1). Any artery may be used since the concentration of metabolites is virtually the same in all arteries. After adequate recovery from the operation, sampling of blood through these catheters together with some means of estimating blood flow is used to estimate net inflow/outflow (typically referred to as 'net flux') of metabolites across the whole of the portal-drained viscera (PDV) and liver. It has also proved possible to estimate the net movement of metabolites across sections of the PDV, such as the mesenteric-drained viscera (MDV) or the rumen. Moreover, the combination of A-V differences, blood flow and other measurements, such as nutrient disappearance from the lumen of the gut, or isotopic extraction and interconversion provides invaluable insight into the quantitative metabolism of absorbed nutrients by the splanchnic tissues. The rates of protein synthesis by splanchnic tissues are not dealt with in this Chapter, since these rates are described in Chapter 14. 
The general principles have been well described by Bergman (1975); van der Walt et al. (1983); Pethick et al. (1981) and Pell et al. (1986).

\section{Portal-drained viscera}

Net exchange (flux)

Net flux of compound,

$$
x_{m}=\left(P_{m}-A_{m}\right) \times P B F
$$

Where:

$P B F=$ portal blood flow; $P_{m}$ and $A_{m}$ are the portal and arterial blood concentrations of metabolite $m$. If $P_{m}>A_{m}$ net flux of $m$ is positive (there is net release or absorption into venous blood). If $P_{m}<A_{m}$ net flux of $m$ is negative (there is net uptake or removal from arterial blood).

True (gross) release and removal

By infusing isotopically labelled $m$ one may distinguish release and utilisation when both occur simultaneously. Since the earlier edition, most isotopic studies have been made with stable (nonradioactive) isotopes. Enriched $m$ is infused at a constant rate into any peripheral vessel, which is usually the jugular vein. After some time a steady state may be assumed (enrichments do not change with time). The period of infusion used may also be based on reaching a plateau enrichment of a metabolite of $m$, such as $\mathrm{CO}_{2}$.

The isotopic input of $m=A_{m} \cdot E_{a m} \cdot P B F$

The uptake of isotopic $m=P B F \cdot\left(P_{m} \cdot E_{p m}-A_{m} \cdot E_{a m}\right)$

Fractional uptake of isotopic $m=$ Eqn $12.2 /$ Eqn $12.3=\left[\left(P_{m} \cdot E_{p m}\right) /\left(A_{m} \cdot E_{a m}\right)\right]-1$

Where:

$E_{p m}=$ enrichment $(\mathrm{APE}=$ atom percent excess $)$ of $m$ in portal vein; and $E_{a m}=$ enrichment of $m$ in artery.

The true $($ gross $)$ uptake $=$ input of $m \times\left(\right.$ Eqn 12.4) $=P B F \cdot A_{m} \cdot\left[\left(P_{m} \cdot E_{p m} / A_{m} \cdot E_{a m}\right)-1\right](12.5)$

This assumes that over a short period no labelled $m$ is released to the circulation by the tissue examined. This may not be true for all metabolites resulting in underestimation of unidirectional uptake. Thus the following should be regarded as best estimates.

True (gross) release is the sum of the true uptake plus the net flux, thus: 
true release $\left.=P B F\left\{P_{m}-A_{m}+A_{m} \cdot\left[\left(P_{m} \cdot E_{p m}\right) /\left(A_{m} \cdot E_{a m}\right)\right]-1\right)\right\}=$ $P B F\left[P_{m}-A_{m}\left(P_{m} \cdot E_{p m}\right) /\left(A_{m} . E_{a m}\right)\right]$

\section{Oxidation}

Measurement of oxidation of $m$ by measuring production of ${ }^{3} \mathrm{H}$ or ${ }^{2} \mathrm{H}$ across the gastrointestinal tract (GIT) is impracticable because of the large flux of water across it. If ${ }^{13} \mathrm{C}-m$ is used, letting $P_{\mathrm{CO} 2}$ and $E_{P C O 2}$ be the concentration and enrichment of $\mathrm{CO}_{2}$ in portal and $A_{C O 2}, E_{A C O 2}$ the values in arterial blood, then:

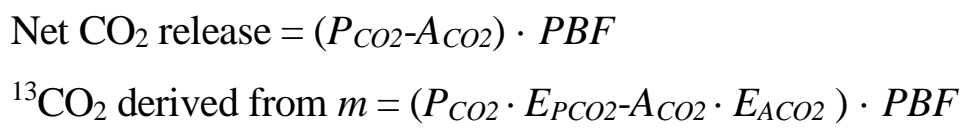

To express the fraction of $\mathrm{CO}_{2}$ derived from $m$ this is divided by the enrichment of precursor $m$. This requires an assumption as to the enrichment of $m$ in the tissues being studied. It is usually taken as the venous specific activity although the value is perhaps more likely to lie between arterial and venous. For further discussion of this point, see also France et al. (1999).

Fraction of $\mathrm{CO}_{2}$ derived from $\left.m=\left[\left(\mathrm{P}_{\mathrm{CO} 2} \cdot E_{\mathrm{PCO} 2}-A_{\mathrm{CO} 2} \cdot E_{\mathrm{ACO} 2}\right) \cdot P B F\right] / E_{\mathrm{Pm}}\right]$

The fraction of $m$ uptake oxidised by the site studied is given as Eqn 12.8/Eqn 12.5.

One concern with the use of ${ }^{13} \mathrm{C}$ to determine oxidation of $m$ is the amount of labelled $m$ required to measurably enrich $\mathrm{CO}_{2}$. For many metabolites with low rates of oxidation, the infusion rate of ${ }^{13} \mathrm{C}-m$ required for measurable enrichment of $\mathrm{CO}_{2}$ may be such a large proportion of daily $m$ turnover that metabolic responses to the ${ }^{13} \mathrm{C}-m$ occur, and thus the principles of tracer methodology are violated.

Interconversion of metabolites

To determine the interconversion of glucose and lactate (or leucine/ketoleucine; 3hydroxybutyrate/acetoacetate) compartmental analysis is required. Estimates of rates will then depend on the model assumed. Fig. 12.2a shows a model in which glucose and lactate represent homogeneous compartments each communicating with a 'sink' (this is conceptual-it may represent part of the cell, such as glycogen; or it could be the gut lumen). There are 10 rate constants, of which $R_{01}, R_{02}, R_{10}$ and $R_{20}$ can be determined experimentally from glucose and lactate concentrations and enrichments and blood flow. This leaves six unknown. Equations for carbon balance for the glucose and the lactate pools supply two equations (e.g. for the glucose pool $R_{01}+R_{21}+R_{31}=R_{10}+R_{12}+R_{13}$ ) and with ${ }^{13} \mathrm{C}$ glucose infused, isotope balance for the glucose and lactate pools supplies a further two equations. Thus where $\mathrm{A}$ and $\mathrm{V}$ represent the arterial and venous input, (and assuming the latter reflects the tissue 
pools) we have

$$
\begin{aligned}
& A E_{\text {gluc }} \cdot R_{01}+V E_{\text {lact }} \cdot R_{21}=\left(R_{13}+R_{12}+R_{10}\right) \cdot V E_{\text {gluc }} \\
& A E_{\text {lact }} \cdot R_{02}+V E_{\text {gluc }} \cdot R 12=\left(R_{21}+R_{24}+R_{20}\right) \cdot V E_{\text {lact }}
\end{aligned}
$$

In the same way, results following infusion of labelled lactate yield two further equations for isotope balance for the glucose and lactate pools. Then six simultaneous equations will lead to a unique solution for the six unknown rates.

It may be reasonable to take a simpler model (shown in Fig. 12.2b). Here it is assumed that lactate metabolism occurs only through glucose (this is biochemically improbable, since it is likely that lactate carbon would be metabolised to compounds such as glucogenic amino acids without passing through the glucose pool). However, the amount so utilised might well be small and its neglect may lead to little error. $R_{21}$ is also omitted from the model; this implies that gluconeogenesis from lactate does not occur in the GIT which is almost certainly true. With this simplified model it is not necessary to use two labelled compounds since there are only three unknown rates; the two carbon balance equations, plus the two for isotope balance obtained from use with ${ }^{13} \mathrm{C}$-glucose are more than sufficient to solve for the unknowns. Indeed it is possible to solve without matrix analysis since first $R_{12}$ may be obtained from isotope balance $\left(R_{12}+R_{02}=R_{20}\right)$; then $R_{13}=R_{01}-\left(R_{10}+R_{12}\right)$, since $R_{31}$ does not contribute label. Finally $R_{31}$ is obtained from carbon balance.

Determination of the amount of amino acid 'sequestration' during absorption

The amount of an amino acid 'sequestered' is the amount metabolised in the absorptive cells of the small intestine, either as export or constitutive protein synthesis or by catabolism. Similar approaches could be used for other metabolites if rate of disappearance from the gut lumen can be determined or estimated. The approach requires the differential labelling of both the blood and small intestinal lumen pools, as the recovery of isotope infused into the gut lumen must be corrected for absorbed isotope subsequently extracted (sequestered) by the PDV from arterial blood. Utilisation of blood-derived (arterial) amino acids by the PDV is determined isotopically much as described above. After intravenous infusion of labelled $m\left(I_{1}\right)$, when steady state is reached, $E_{p m}$ and $E_{a m}$ represent respective enrichments of portal and arterial $m$.

The fractional extraction of $I_{l}$ from arterial blood $\left(S_{l}\right)=\left(A_{m} E_{a m}-P_{p m} E_{p m}\right) / A_{m} E_{a m}$

A different isotope $\left(I_{2}\right)$ of the amino acid is also infused into the duodenum (or the same isotope could be infused on a separate occasion), and its fractional disappearance from the small intestinal lumen is calculated as: (Infused $I_{2}$ - Ileal $I_{2}$ )/ Infused $I_{2}$.

The true fractional recovery of $I_{2}$ in the portal system is calculated as:

$$
\left(S_{2}\right)=\left(P_{m 2} \cdot E_{p m 2}-A_{m 2} E_{p m 2}\right)+S_{I}\left(A_{m 2} E_{p m 2}\right) \cdot P B F /(\text { Infused } I-\text { Ileal } I)
$$


The fraction sequestered $=1-S_{2}$

The amount sequestered is then given as:

$\left(1-S_{2}\right) \cdot($ apparent absorbed amino acid + ileal endogenous amino acid)

Apparent absorbed amino acid and ileal endogenous amino acid are obtained from separate (nonisotopic) experiments using measurements of duodenal and ileal flow and an estimate of endogenous flow in the ileum (e.g. MacRae et al., 1997a).

\section{Mesenteric-drained viscera}

The calculations are identical with the ones above, substituting mesenteric for portal vein.

\section{Liver}

In this case, the calculations are somewhat more complicated since the hepatic input is the sum of the portal output plus the arterial input (taking the flow as that of the hepatic artery). The output is that from the hepatic veins. Otherwise the calculations are as above, except that in calculating metabolic interactions gluconeogenesis and ureagenesis are of considerable importance.

\section{Irreversible loss (ILR)}

Finally, when labelled $m$ is infused intravenously under steady state conditions the total ILR of $m$ from the blood pool can be determined:

$$
\operatorname{ILR}=I / A_{m}
$$

Again, the choice of sampling site for measuring enrichment of $m$ is critical, but in most cases whole body ILR is calculated using the arterial pool, in some cases with correction for liver (and gut) sequestration during absorption of $m$ (Bergman, 1975). For essential amino acids, this ILR is equal to their use for protein synthesis and oxidation, which will be equal to their release from protein degradation and absorption from the gut lumen.

\section{Requirements of the A-V difference method}

The A-V difference technique is now widely used since many workers can prepare and maintain catheterised animals that can be useable for months or years. Crucial features are the ability to measure accurately both blood flow and small A-V differences. For blood flow measurement, infusion of a 
marker such as $\rho$-amino-hippurate (PAH) has been widely used. The method involves infusion into the blood at one point and measurement of concentration down-stream. Substantial extraction by kidney $(\mathrm{PAH})$ or liver is required each circulation time to maintain a constant background (arterial) concentration of marker. It is also possible to inject 'cold' saline and measure the temperature change. This method has been used successfully, but requires meticulous attention to technique. When PAH is used portal vein and liver blood flow can be measured simultaneously, and the hepatic artery flow calculated by difference.

Other techniques have been described for measurement of blood flow, including electronic methods using a 'cuff' or 'probe' around a vessel such as the portal vein or hepatic artery. Electromagnetic or ultrasound/Doppler shift techniques were used earlier. The disadvantage was that estimation varied with the diameter of the vessel and this changed with time. Another technique involves a probe with a yoke around the vessel that measures fluid flow through a beam of ultrasound. The probe measures transit time of blood through the probe, which is a function of the volume flow through the beam (Drost, 1978). Estimation is independent of vessel diameter if probe size and alignment within the vessel are correct. Both instant and time-averaged flow is possible. This method has not generally been feasible in cattle, because of difficulties in probe placement about the portal vein. As opposed to sheep, who have a common portal vein, the convergence of the gastrosplenic and anterior mesenteric veins typically occur at the porta hepatis in cattle. Huntington et al. (1990) have described such a technique in young steers, but encountered problems in correctly placing the probe on the portal vein. Few comparisons have been made of the ultrasound and dye dilution techniques. However Rémond et al. (1998) have shown that in sheep, results with a new cuff-type transit-time ultrasound probe (A type) agreed fairly well with dye dilution $( \pm 10 \%)$. This new type of probe would be much easier to place on the portal vein of cattle than the type of probes used by Huntington et al. (1990). Rémond et al. (1998) concluded absolute accuracy of such flow estimations was within 5\% for portal flow. It is still necessary to determine hepatic flow independently. This may be obtained by a clearance technique, using compounds such as indocyanine or bromsulphthalein, which do not depend on adequate mixing in the portal vein. Alternatively, a smaller electronic probe can be used to measure hepatic artery flow directly (Ortigues et al., 1996).

The importance of precision in A-V difference measurement is indicated by comparing the measurement of oxygen consumption and carbon dioxide production-in one experiment, oxygen concentrations in arterial, portal and hepatic vessels were 4.3, 3.0 and $1.0 \mathrm{mM} ; \mathrm{CO}_{2}$ concentrations were 27.2, 28.4 and $29.6 \mathrm{mM}$. While the fractional difference across the tissues for oxygen is $0.2-0.3$, the corresponding difference for $\mathrm{CO}_{2}$ is only about 0.04 , a change much more difficult to quantify. Measurement of $\mathrm{CO}_{2}$ production by the PDV is also complicated because $\mathrm{CO}_{2}$ derives from fermentation and saliva in the gut lumen, as well as the PDV tissues, and can be transferred from blood 
to the gut lumen.

Limitations of the method

Limitations of the A-V difference method include:

1. Loss of patency of even one catheter may prevent use of an animal. The arterial sample is essential, thus the carotid artery is often elevated to a subcutaneous position to allow insertion of a temporary catheter (Huntington et al., 1989). In addition, the use of PAH for measuring blood flow is dependent on a patent and appropriately placed mesenteric vein catheter for PAH infusion, thus two catheters are often established to provide a backup if one loses patency or gives invalid results.

2. Incomplete mixing in blood vessels may result in over- or underestimation of an A-V difference and an error in blood flow estimation if a dilution method is used. Therefore, mesenteric infusion catheters should be established with their tips as far as possible from portal and mesenteric vein sampling sites, and portal vein sampling catheters should be inserted downstream from the porta hepatis, where turbulence helps to mix portal blood as it is delivered to the liver.

3. The PDV are a heterogeneous group of tissues. More recent methods in which catheters are implanted both before and after the conjunction of anterior mesenteric and gastrosplenic vein, permit partitioning into 'pre-' and 'post-stomach' metabolism. This is an improvement but both components remain heterogeneous.

4. There is no common hepatic vein; nearly all studies have relied on the same major hepatic vein and sample a similar region of the liver. There is little information on possible site variation in hepatic metabolism, but strong evidence for regional distribution of anterior mesenteric and gastrosplenic blood, especially in younger animals (Heath and Perkins, 1985).

5. Ideally, one should estimate 24-hour integrated values for blood flow and metabolite concentration but this is rarely done. Hourly feeding reduces but does not eliminate variation over 24 hours, depending in part on the level of intake prescribed, and may well distort 'normal' metabolism. In addition, in the authors' experience, it is difficult to arrange hourly feeding of sheep in late pregnancy or with suckling lambs. The best that can be done is to feed 3-4 meals per day of concentrates with free feeding of forage. This may also be true for lactating dairy cows if the capacity of automated feeders is limited.

\section{OXYGEN CONSUMPTION}

In the first edition evidence was presented that oxygen uptake by the splanchnic tissues of sheep 
and cattle was about $40-50 \%$ of total body

oxygen consumption, with roughly equal contributions by the viscera and the liver. There is now much more evidence supporting this conclusion (see e.g. Reynolds, 2002). In addition much new evidence shows that the amount of food consumed and digested is a significant factor determining oxygen uptake by these tissues. Fig. 12.3 shows that for both sheep and cattle, oxygen consumption of both viscera and liver is related to digestible energy intake. The slope of these equations suggests that these tissues in the course of digestion use the equivalent of $8 \%$ in sheep and $13-14 \%$ in cattle of the digestible energy input. It is tempting to suppose that during absorption of nutrients, this proportion is therefore directly utilised - what Reynolds (2002) has described as a 'toll-keeping' charge. However, more critical examination suggests this is an over-simplification. In fasted sheep, oxygen uptake is equivalent to about $1.14 \mathrm{MJ} \mathrm{d}^{-1}$ for PDV and $1.97 \mathrm{MJ} \mathrm{d}^{-1}$ for liver and in cattle 6.34 and $8.71 \mathrm{MJ} \mathrm{d}^{-1}$ correspondingly. These values are significantly larger than the intercept values for the above equations. Thus at least part of the energy consumption is related to maintenance requirements, rather than being directly related to nutrient assimilation. This would be consistent with the thesis developed by Reynolds (2002) that the greater part of the energy and nutrient costs associated with absorption of food is derived from arterial blood. At present it is still unknown what additional factors, dietary or endogenous, determine energy consumption by the viscera. Noziere et al. (2000) have shown, infusing varying mixtures of SCFA, that differences in the molar proportions of these acids in the rumen has no significant effect on the total energy absorbed into the portal vein, although they did not measure possible effects on visceral oxygen consumption.

\section{EFFICIENCY OF NUTRIENT ABSORPTION INTO THE PORTAL VEIN}

A major issue discussed in the earlier edition of this Chapter was the discrepancy between disappearance of nutrients from the gastro-intestinal tract and their appearance in the portal vein. This is frequently illustrated by the comparisons made by Bergman and Wolff (1971) of the net and true PDV release of SCFA in sheep with previous measurements at another location of net SCFA production in the rumen of sheep fed a similar diet. In this case, comparison of PDV release with rumen production suggested a considerable amount of sequestration during absorption. These observations were supported by the extensive metabolism of SCFA by rumen epithelial tissue in vitro, as well as subsequent studies in which the SCFA were ruminally infused in multicatheterized sheep and cattle (Reynolds, 2002).

\section{Short chain fatty acids}


The metabolism of SCFA by the PDV has been re-examined recently by Kristensen et al. (2000a). The authors used catheterised sheep with the rumen temporarily isolated, washed free of rumen contents and filled with buffered salts ( $\mathrm{pH}$ 7.1). In these conditions, the net release (flux) in

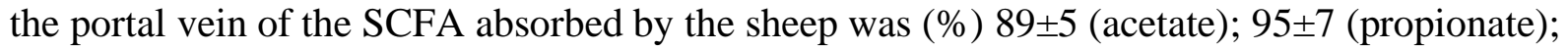
$102 \pm 9$ (isobutyrate); $23 \pm 3$ (n-butyrate); $48 \pm 5$ (isovalerate); and $32 \pm 4$ (valerate). Because $2-{ }^{13} \mathrm{C}$ acetate was infused intravenously, it was possible to correct net acetate release for arterial blood acetate removal by the PDV as described earlier. Corrected in this way, acetate release was $109 \pm 7 \%$, and the increase in ILR was $101 \pm 7 \%$, of the acetate absorbed from the rumen. The additional 'recovery' of acetate in this case may reflect endogenous release by PDV tissues. Pethick et al. (1981) had shown (by using ${ }^{14} \mathrm{C}$-labelled blood acetate) that in sheep on a maintenance ration, nearly $80 \%$ of the acetate utilised by the PDV was oxidised, accounting for possibly $50 \%$ of the energy used by the PDV. There is thus a clear distinction between acetate absorption (which is quantitatively recovered) and blood acetate, which meets (in part) the energy needs of the PDV as Reynolds (2002) had indicated. The almost complete recovery of absorbed propionate in the portal vein suggests that during absorption by the epithelia it is not appreciably oxidised, or metabolised to other metabolites. The arterial concentration of blood propionate is too low for it to act as an energy source for the remainder of the PDV. It has been suggested that propionate is in part converted to lactate, but evidence suggests this is at best a minor pathway (2 5\%) (Weekes and Webster, 1975). The low recovery of n-butyrate is attributed to partial conversion to 3-hydroxybutyrate, a reaction that has been known for about 50 years to occur in rumen epithelium. However, measurement of the extent of this conversion has only recently been quantified by Kristensen et al. (2000b). Sheep were infused via the rumen with either water or nbutyrate. Recovery (increment in net PDV release over the water control) of added n-butyrate was only $19 \%$. However, assuming 3-hydroxybutyrate appearing in the portal vein was also derived from rumen n-butyrate, recovery increased to $43 \% .{ }^{13} \mathrm{C}$-labelled 3-hydroxybutyrate was also infused into a mesenteric vein, so that it was possible to determine uptake of 3-hydroxybutyrate by PDV tissues from arterial blood. This correction increased the total recovery of ruminal n-butyrate to $65 \%$. The authors did not measure acetoacetate, but Lindsay and Oddy (1985) reported in sheep net PDV acetoacetate production of 1.0-3.6 mmol h${ }^{-1}$, accompanying a net PDV 3-hydroxybutyrate production in the range reported by Kristensen et al. (2000b). It is plausible therefore that if account were taken of probable acetoacetate production, portal recovery of n-butyrate as 4-carbon compounds would be $80 \%$ or more.

The $\mathrm{C}_{5}$ acids and isobutyrate are derived from the catabolism in the rumen of branchedchain amino acids. The total amounts available are always small relative to the other SCFA. Isobutyrate, which is glycogenic, might in part be released as methyl malonic or succinic acid, 
although in the study above (Kristensen et al., 2000a) recovery was essentially complete. Isovaleric is ketogenic while valeric is both glycogenic and ketogenic. They may also be partly metabolised in the rumen epithelium. Overall, the total (2-5)-C compounds appearing in the portal vein can account for at least $80-90 \%$ of the amount of SCFA produced in the rumen and caecum. It is at present assumed that the remaining difference may be due to oxidative metabolism during absorption or microbial utilisation of SCFA in the digestive organs.

\section{Long-chain fatty acids (LCFA)}

So far as we are aware no new studies have appeared in the last few years aimed at quantifying the absorption and metabolism of LCFA. It may be in part because of technical difficulties. Durand et al. (1990) presented evidence in pre-ruminant calves that as much chylomicra and VLDL may be absorbed via the portal vein as are absorbed via lymphatics. Moreover it is difficult to distinguish LCFA released from the gastro-intestinal tract from that released from adipose tissue. As stated in the earlier edition, approximately $20 \mathrm{~g} \mathrm{~d}^{-1}$ of LCFA is absorbed via the lymph duct in sheep on a hay diet. In dry cattle the estimates were $200 \mathrm{~g} \mathrm{~d}^{-1}$ and in lactating cows $400 \mathrm{~g} \mathrm{~d}^{-1}$. Bergman et al. (1971) showed that about $15 \%$ of circulating triacylglyceride LCFA utilised was taken up by the PDV of sheep. If oxidised this would substantially contribute to energy needs of the PDV; but this utilisation may also represent uptake and storage of triglyceride LCFA by portal-drained adipose tissue.

\section{Glucose}

The low net portal vein absorption of glucose, even when diets high in starch are fed, has been recognised for some years. It is now clear that when starch or glucose is infused into the abomasum, glucose may be incompletely recovered in the portal vein on a net basis. Kreikemeier and Harmon (1995) made infusions into cattle abomasum of glucose, maize starch or maize dextrin $\left(66 \mathrm{~g} \mathrm{~h}^{-1}\right.$ for each). Only $73 \%$ of glucose that disappeared from the small intestine appeared as increased net PDV release of glucose. For dextrins the value was $60 \%$ and for starch $57 \%$. In other studies, net recovery in the portal vein of glucose derived from starch infused into the abomasum has ranged from $25-51 \%$ (Reynolds, 2002). This low net recovery is in part due to increased metabolism of arterial glucose within the PDV. Reynolds and Huntington (1988) were able to measure in cattle release of glucose into the mesenteric vein (MDV) as well as the portal vein (MDV + stomach tissues). On a lucerne diet, glucose was removed by MDV (22-26 $\left.\mathrm{mmol} \mathrm{h}^{-1}\right)$, which was greater than that by the stomach $\left(5-16 \mathrm{mmol} \mathrm{h}^{-1}\right)$. When a concentrate diet rich in maize meal was fed, there 


\section{1}

was net release of glucose across the MDV (29 $\mathrm{mmol} \mathrm{h}^{-1}$ ) while glucose removal by the stomach substantially increased $\left(31 \mathrm{mmol} \mathrm{h}^{-1}\right)$, perhaps reflecting omental adipose use. One might reasonably suppose that on the maize diet, MDV glucose removal resulted in significant underestimation of the amount of glucose absorbed. In studies with sheep on a maize diet (Janes et al., 1985), intravenous infusion of ${ }^{14} \mathrm{C}$-glucose permitted measurement of arterial glucose utilisation at the same time as net absorption of glucose in the MDV. The rate of removal (which was not affected by change from dried grass to a maize diet) was about $20 \%$ of the rate of net appearance of glucose. In a recent study in cattle (Harmon et al., 2001), when account was taken of increased arterial glucose utilisation by the PDV (measured as above by infusion of ${ }^{14} \mathrm{C}$-glucose) following infusion of starch into the abomasum, apparent recovery (as glucose) in the portal vein increased from 51 to $71 \%$.

Even taking arterial glucose utilisation by PDV into account, it is possible that we can still not fully account for recovery of starch escaping rumen fermentation. This may be due to some metabolism of glucose within the small intestine, perhaps to supply glyceride for the absorption of LCFA. Release as lactate however, does not seem to be important (Reynolds and Huntington, 1988).

\section{Amino Acids}

It has been recognised for some years that there is incomplete net recovery in the portal vein of amino acids disappearing from the small intestine of ruminants, as was first shown by Tagari and Bergman (1978). Likely reasons were discussed in the earlier edition, major factors being utilisation of amino acids for protein turnover and gut protein secretions. Supportive evidence came from estimation of endogenous protein secretion and absorption using ${ }^{15} \mathrm{~N}$-labelled diets (van Bruchem $e t$ al., 1997). In sheep about $3 \mathrm{~g} \mathrm{~d}^{-1}$ endogenous nitrogen appeared in the proximal duodenum, increasing to $10 \mathrm{~g} \mathrm{~d}^{-1}$ at the distal duodenum and falling to $5 \mathrm{~g} \mathrm{~d}^{-1}$ at the ileum. There is now much direct evidence supporting the concept of substantial amino acid utilisation to support endogenous protein synthesis. MacRae et al. (1997b) measured disappearance of several essential amino acids from the small intestine and their net release into the mesenteric and portal vein of sheep. As Fig. 12.4 shows, there was a substantially greater recovery in the mesenteric than in the portal vein. There is thus significant utilisation of these essential amino acids in the stomach and other tissues not drained by the anterior mesenteric vein, presumably for synthesis of secreted and constitutive epithelial proteins. In dairy cows $99 \%$ of absorbed EAA was recovered (measured in separate animals equipped with duodenal and ileal cannulas) in the mesenteric vein, but only $61 \%$ in the portal vein (Berthiaume et al., 2001). For the NEAA, recovery was about $76 \%$ in the mesenteric 
vein but only $38 \%$ in the portal vein. It thus appears the NEAA were more extensively metabolised than the EAA. It is likely that this reflects greater oxidation of the NEAA.

A more direct approach was taken by MacRae et al. (1997a). They measured in sheep the sequestration of labelled amino acids, (using either mixed $\mathrm{U}-{ }^{13} \mathrm{C}$-amino acids or $1-{ }^{13} \mathrm{C}$ leucine) from arterial blood or during absorption, as described previously. Extraction of label was measured either during absorption of amino acids between the jejunum and ileum; or from arterial blood by the total PDV. For the PDV, the fractional extraction of labelled essential amino acids from arterial blood ranged from 0.126 (leucine) to 0.06 (histidine). Portal vein recovery of most labelled essential amino acids infused into the jejunum was $76-82 \%$, but lower recovery was measured for phenylalanine $(65 \%)$ and histidine (61\%). In total, PDV utilisation (arterial and intestinal sequestration) accounted for 32 (histidine) to 65 (valine) $\%$ of whole body flux of the essential amino acids studied. These results clearly showed that most of the essential amino acids metabolised (presumably for endogenous protein secretions) by the PDV were derived from the arterial supply (about 80\%, except for phenylalanine, where it was around 50\%).

Reynolds et al. (2001) applied this technique in dairy cattle at two feed intakes in late lactation (mean $15.4 \mathrm{~kg} \mathrm{~d}^{-1}$ milk yield) and dry period. Their results confirmed the findings by MacRae et al. (1997a) in sheep, that the arterial supply is a major source for metabolism of essential amino acids by the PDV, and this is more striking for leucine than for phenylalanine, especially in dry cows. They also found that increasing food intake increases this metabolism. Most of the metabolised essential amino acids are probably anabolised for the synthesis of secreted proteins, rather than catabolised. Yu et al. (2000) found that about $15 \%$ of the arterial leucine sequestered by the PDV was oxidised; and of that sequestered during absorption, only $0.1 \%$ was oxidised. There is some production of keto-isocaproate and other branched-chain keto acids in the portal vein of sheep (Pell et al., 1986) and cattle (Early et al., 1987). However, at least for leucine, such production is likely to be at most $5 \%$ of the total metabolised.

Further studies using lactating cows have shown that the pattern of amino acids absorbed by the small intestine, or site of absorption, may itself affect metabolism. Caton et al. (2001) have shown that when amino acids are supplied as casein infused into the abomasum, there is increased absorption of amino acids into the portal vein, but little increase in PDV sequestration of leucine or phenylalanine during absorption or from arterial blood. In contrast, when an equivalent amount of essential amino acids is supplied as free amino acids, there is both increased absorption and sequestration, both during absorption and via extraction of the arterially supplied amino acids. The mechanism behind this is not yet understood. It may reflect absorption of an 'unbalanced' mixture of amino acids, or may be related to the site of absorption. Presumably, free amino acids infused into the abomasum will be absorbed in the upper small intestine, whilst casein amino acids will be 


\section{SCFA ABSORPTION}

In studies published in the last 10 years, the correlation between SCFA absorption (net PDV release) and digestible energy (DE) intake of sheep is not high $\left(\mathrm{R}^{2}\right.$ about 0.5$)$. However, the relation is substantially better for cattle $\left(\mathrm{R}^{2}=0.95\right)$, where measurements across a much wider range of DE intakes have been published (Fig. 12.5). For sheep the total net PDV absorption of SCFA (and lactate) was about $46 \pm 3.1 \%$ of DE intake and for cattle $53 \pm 2.5 \%$, but this underestimates true absorption to the extent these acids are utilised by the PDV. Perhaps surprisingly, there was a positive correlation between 'ketogenic' (acetate, n-butyrate, 3hydroxybutyrate) and 'glycogenic' (propionate, lactate and isobutyrate) SCFA release by the PDV (Fig. 12.6). In relation to production in the rumen, it has generally been considered that the two components are negatively related (e.g., Rook, 1976). However, this is largely indicative of changes in diet composition, as opposed to changes in SCFA appearance across a range of DE intakes. Where total amounts of SCFA absorbed are driven primarily by the amount of organic matter fermented in the gut they are positively related across a range of intakes. We have seen that the lower rates of appearance of SCFA in the portal vein compared to rates of production in the rumen may be attributed to metabolism in the PDV. The pattern of metabolites used by the PDV may be affected by the pattern produced in the rumen, so that increased production of acetate units leads to its greater oxidation by the PDV. Since metabolism is primarily from blood-derived nutrients, this could readily be tested.

\section{HEPATIC METABOLISM}

\section{Glucose production}

The strong relation in sheep and cattle between DE and glucose ILR as determined by isotope dilution has been known for more than 30 years. Since about $90 \%$ of glucose production is derived from the liver, it is to be expected that there will be a correspondingly close relation between DE and hepatic glucose release, and as Fig.12.7a shows this is seen in cattle. In the studies in sheep the relation is marginally significant $\left(\mathrm{R}^{2}=0.2\right)$, but as mentioned previously the range of intakes is less. In cattle, there is a strong positive relation between hepatic glucose release and propionate removal $\left(\mathrm{R}^{2}=0.91\right)($ Fig. 12.7b) although not for glucose release and lactate removal. This likely reflects the fact that both hepatic glucose production and propionate absorption (and hepatic removal) are 
highly correlated with DE intake, whilst lactate uptake by the liver varies with the supply of other glucose precursors and the extent of Cori cycling (Reynolds, 1995). In contrast to cattle, in sheep there is no significant relationship between propionate removal and glucose release, although a significant one for lactate removal and glucose release $\left(R^{2}=0.6\right)$, which again may reflect greater variation in glucose requirement within a smaller range of feed intake. In cattle, on average, propionate, lactate and isobutyrate removal are sufficient to account for $73 \pm 4 \%$ of hepatic glucose release and the mean value in sheep is probably very similar (see references for Fig. 12.5 and 12.6). Few measurements were reported for isobutyrate removal but removal of propionate and lactate alone could account for $71.5 \pm 7.9 \%$. Even fewer measurements are reported for liver glycerol removal although it can account for 5-20\% of glucose output. In fed animals however, the lower figure is more realistic. Propionate extraction by the liver was slightly less complete in sheep (86\%) than in cattle $(92 \%)$.

Eisemann and Huntington (1994) and Eisemann et al. (1997) have clarified the effect of insulin on glucose release. Firstly the response is lower with increasing age as occurs with nonruminants. Secondly the liver is more sensitive to insulin than peripheral tissues (as exemplified by hindquarters). Thus $\mathrm{ED}_{50}$ for liver (the arterial concentration required to have $50 \%$ of the maximum effect) is $44 \pm 11 \mu \mathrm{U} \mathrm{ml}^{-1}$ in young cattle and $89 \pm 22 \mu \mathrm{U} \mathrm{ml}^{-1}$ in older animals. For the hindquarters, respective values are $243 \pm 78$ and $488 \pm 151 \mu \mathrm{U} \mathrm{ml}^{-1}$, but this may relate, in part, to the proportion of cardiac output received by these tissue beds.

\section{Fatty acid metabolism}

This topic has been much less studied in the last few years. Normally in fed sheep and cattle liver nbutyrate and acetoacetate are almost completely removed whereas there is usually a release of acetate and 3-hydroxybutyrate. Recent studies show liver release of the two are both significantly correlated to liver n-butyrate removal (although $\mathrm{R}^{2}$ is only about 0.3 ). $\mathrm{n}$-Butyrate is an obvious source of 3-hydroxybutyrate and studies in cattle of liver 3-hydroxybutyrate release in response to n-butyrate infusions have indeed shown a significant correlation between the two (Fig. 12.8a). However, the slope of the linear relation (about 2 in cattle and >3 in sheep) indicates that 3 hydroxybutyrate release is substantially greater than n-butyrate removal. Non-esterified fatty acids (NEFA) are an obvious source of the additional carbon. Unfortunately there are few publications with additional information on NEFA uptake by the liver. However data by Krehbiel et al. (1992) and Reynolds et al. (1992b) in cattle shows (Fig. 12.8b) that there is a strong $\left(\mathrm{R}^{2}=0.96\right)$ relation between removal of NEFA, n-butyrate, and acetoacetate, and release of 3-hydroxybutyrate and acetate. However the slope of the line is still $>1$ (1.61) leaving the origin of all the ketogenic 
carbon uncertain. Moreover, some NEFA must be oxidised, and some would be released as esterified lipid, especially triacylglycerides. The most likely origin of the additional carbon is from the oxidation of amino acids. There does not seem to be comparable information relating to sheep. In pregnant sheep Freetly and Ferrell $(1998 ; 2000)$ reported release of acetate and triacylglycerides and removal of NEFA and n-butyrate, but unfortunately no measurement of 3-hydroxybutyrate and acetoacetate. Triacylglyceride and acetate release would account for 34, 22 and $43 \%$ of the carbon taken up as NEFA and n-butyrate in dry, single or twin pregnant ewes; the remaining carbon could allow a maximum release of 7.5, 22.9 and $22.3 \mathrm{mmol} \mathrm{h}^{-1}$ of ketones respectively. In practice, as reported in the first edition, ketone output even in healthy twin-pregnant sheep can be about 30 $\mathrm{mmol} \mathrm{h}^{-1}$. Since some oxidation of NEFA is also to be expected, again this implies another carbon source for this purpose. However it should be appreciated that triacylglycerides, like acetate and acetoacetate can be taken up as well as released (Reynolds et al., 2003a). For complete estimates of carbon balance all metabolites should be measured in the same animals under similar conditions. These points are more fully discussed by Hanigan et al. (2004).

\section{Nitrogen metabolism}

One of the most striking characteristics of ruminants is the extensive degradation of nitrogenous compounds in the rumen. Much of the nitrogen is reduced to ammonia, which is absorbed into the portal vein if not utilised by rumen microbes. The amount so absorbed depends to some extent on the nitrogen intake. For sheep the relationship is weak $\left(R^{2}=0.17\right)$ but much stronger for cattle $\left(R^{2}=\right.$ 0.92) as Fig. 12.9a shows. Overall for cattle the mean value for the net appearance of ammonia in the portal vein as a percentage of nitrogen intake is $48 \pm 2 \%$ and for sheep $32 \pm 2 \%$. Ammonia in significant concentration in peripheral blood is toxic, through effects on the central nervous system. It is essential for the liver to remove it effectively, by conversion to urea or amination reactions such as the synthesis of glutamine from glutamate. In practice, hepatic removal of $\mathrm{NH}_{3}$ is often a little less than the PDV release in cattle $(95 \pm 8 \%)$, but greater in sheep $(111 \pm 1 \%)$. Ammonia removal by the liver could account in cattle for $71 \pm 2 \%$ of the urea-nitrogen produced, but rather

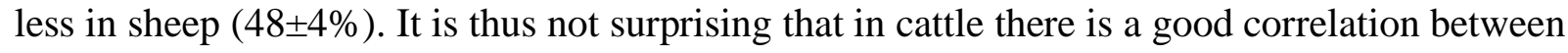
ammonia removal and urea release $\left(\mathrm{R}^{2}=0.82\right)($ Fig. 12.9d) which is not improved when removal of $\alpha$-amino-N is also taken into account. In sheep however, there is a very weak correlation within the studies reported $\left(\mathrm{R}^{2}=0.15\right)$. However, when $\mathrm{NH}_{3}$ is infused into the mesenteric vein of sheep there is a strong correlation between ammonia removal by the liver and release of urea (Milano et al., 2000) with $\mathrm{R}^{2}=0.89$ and a slope not significantly different from $1 \mu$ mole urea $\mathrm{N}$ released $\mu$ mole ${ }^{-1}$ $\mathrm{NH}_{3}-\mathrm{N}$. 
In the PDV the urea concentration is

almost always lower than arterial, so that urea is taken up by PDV and, after hydrolysis by ureases, may be used for bacterial protein synthesis. This return of urea occurs to some extent throughout the gastrointestinal tract. However, bacterial protein formed in the large intestine is probably simply lost in the faeces. In contrast, ammonia-N returned to the rumen can be incorporated into protein that may subsequently be hydrolysed and the amino acids or peptides formed absorbed in the small intestine. Quantitatively, the rumen must be the main site of potential bacterial protein synthesis. There have been several studies in cattle in which both mesenteric and portal absorption have been measured (Reynolds and Huntington, 1988; Huntington, 1989; Seal et al., 1992; Seal and Parker, 1994; Huntington et al., 1996; Theurer et al., 2002). These allow estimates of the fraction of urea taken up by the PDV which passes to the rumen. In these studies about $82 \pm 6 \%$ was taken up by the rumen. The other significant source of urea transport to the rumen is via saliva. This has been estimated from the rate of urea production by the liver less that lost from blood to the PDV or by urinary excretion. The amount transferred in this way seems to vary greatly in different studies, perhaps mainly due to different effects of diet. In the studies above, when account was taken of salivary urea, the rumen appeared to account for $73 \pm 7 \%$ of urea transferred to the gastrointestinal tract. The recycling of nitrogen in this way is of great significance in ruminants. Lapierre and Lobley (2001) have estimated that $45-60 \%$ of urea-N is anabolised. Moreover, they show that nitrogen may recycle repeatedly, increasing the chance of anabolic conversion to protein by $20-50 \%$. It is this feature that explains how hepatic urea-N production can in some circumstances be greater than dietary $\mathrm{N}$.

It is not clearly established what factors might result in increased transfer of urea from blood to PDV. It had earlier been suggested that arterial urea concentration might be a driving force. However, there is no correlation between arterial urea and PDV urea transfer. It is feasible that with increased energy available for bacterial protein synthesis, availability of nitrogen could be limiting and met by drawing in urea (see Chapter 10). In beef cattle, a greater proportion of urea transfer to the PDV occurred across stomach tissues when a high concentrate diet was fed, perhaps due to increased energy supply for microbial fermentation (Reynolds and Huntington, 1988). In contrast, feeding lucerne shifted urea transfer to the MDV, perhaps reflecting an increased fermentation of fibre in the hindgut. In cattle, there is a moderate correlation between DEI and PDV urea transfer $\left(\mathrm{R}^{2}=0.43\right)$. However in sheep there is no significant relationship.

The mean values for nitrogen absorbed as $\alpha$-amino nitrogen are actually less than those absorbed as $\mathrm{NH}_{3}$. In sheep the proportion is $42.5 \pm 2.1 \%$ and in cattle $29.0 \pm 1.6 \%$. For sheep the correlation between portal $\alpha$-amino- $\mathrm{N}$ and dietary $\mathrm{N}$ intake is moderate with $\mathrm{R}^{2}$ about 0.5 but for cattle it is high $\left(R^{2}=0.87\right)$. In cattle there is also a strong relation with DE intake $\left(R^{2}=0.90\right.$; see Fig. 12.9b and c); but for sheep the relation with DE intake is poorer $\left(\mathrm{R}^{2}=0.38\right)$ than that seen with 
$\mathrm{N}$ intake.

One question that has been much discussed since the previous edition is whether the requirement for urea formation from ammonia affects the utilisation of amino acids by the liver. Two features bear on this point. Firstly, in the formation of urea, while the nitrogen for carbamyl phosphate formation is derived from ammonia, the second nitrogen is derived from aspartate. This second nitrogen could be derived from ammonia via glutamate formation; but its requirement could also increase utilisation of amino acids to supply more aspartate by transamination. In fact (see Lobley et al., 2000) studies with ${ }^{15} \mathrm{~N}$-labelled ammonia have shown that in fasted sheep subjected to an overload of ammonia about one-third of aspartate-N was derived from ammonia. Secondly, in contrast, there is a limited capacity for the liver to form urea (approximately $29 \mathrm{~g}$ urea- $\mathrm{N} \mathrm{d}^{-1}$ for a 40 $\mathrm{kg}$ sheep and $435 \mathrm{~g} \mathrm{~d}^{-1}$ for a $600 \mathrm{~kg}$ cow or steer; Lobley et al., 2000). The question then arises whether, when capacity approaches the limit, the liver gives priority to limiting peripheral ammonia or amino acid concentrations. At peak release of ammonia after a meal it is suggested the maximal capacity may be exceeded. Lobley et al. (2000) found that a 30-minute infusion of $2 \mathrm{mmol} \mathrm{min}^{-1}$ of ammonium bicarbonate into the mesenteric vein of sheep was sufficient to result in incomplete removal of the $\mathrm{NH}_{3}$ and the non-ammonia- $\mathrm{N}$ contribution to ureagenesis declined from 0.36 to 0.14 mmol $\mathrm{min}^{-1}$. When an amino acid mixture $\left(1.84 \mathrm{mmol} \mathrm{min}^{-1}\right)$ was infused in sheep fed a diet above maintenance, there was no change in hepatic ammonia removal although a marked arterial hyperaminoacidaemia resulted. Minimising peripheral ammonia increase appears to have the greater priority, at least in the short term. When faced with an excess supply of amino acids, the capacity for ureagenesis from amino acids takes much longer to adapt than is required for increased ammonia supply (Reynolds, 1995).

Apparent nitrogen balance across the liver as measured by the difference between N-output (as urea) and $\mathrm{N}$-input (as $\mathrm{NH}_{3}+$ amino acids) may be either positive or negative. Thus Reynolds $e t$ al. (2001) found a positive value $\left(83 \mathrm{mmol} \mathrm{N} \mathrm{h}^{-1}\right)$ in dry cows given a restricted feed intake (urea release $520 \mathrm{mmol} \mathrm{N} \mathrm{h}^{-1} ; \mathrm{NH}_{3}+$ amino acids removed $603 \mathrm{mmol} \mathrm{N} \mathrm{h}^{-1}$ ). When the same cows received a higher feed intake, the balance became negative $\left(283 \mathrm{mmol} \mathrm{N} \mathrm{h}^{-1}\right.$; urea release 1090 mmol $\mathrm{N} \mathrm{h}^{-1} ; \mathrm{NH}_{3}+$ amino acids removed $797 \mathrm{mmol} \mathrm{N} \mathrm{h}^{-1}$ ). Finally with the same cows lactating, with the higher feed intake, the balance was even more negative $\left(538 \mathrm{mmol} \mathrm{N} \mathrm{h}^{-1}\right.$; urea release 1352 mmol $\mathrm{N} \mathrm{h}^{-1} ; \mathrm{NH}_{3}+$ amino acid removal $814 \mathrm{mmol} \mathrm{N} \mathrm{h}^{-1}$ ). Positive values might be expected since some amino acids must be used for synthesis of proteins known to be secreted by the liver. There are several possible reasons for apparent negative $\mathrm{N}$ balance. Account should be taken of the non- $\alpha-$ amino- $\mathrm{N}$ in amino acids. In the study above, where individual amino acids were measured, this could increase the positive balance by $122 \mathrm{mmol} \mathrm{N} \mathrm{h}^{-1}$; and decrease the negative balances by 187 and $152 \mathrm{mmol} \mathrm{N} \mathrm{h}^{-1}$. However, this would still leave a net negative balance. It is possible that 
Removal of amino acids by the liver is extremely variable. This is to be expected since, with the exception of the branched-chain acids, the liver is the predominant site for the catabolism of amino acids surplus to anabolic needs. Moreover the liver itself is heavily involved in anabolism: in 1-C reactions, in detoxification and in acting as a protein reserve by increasing readily in size in response to increase in protein availability, decreasing as it becomes inadequate. Lobley et al. (2000) found in a survey of 8 studies of sheep and cattle, that the fractional extraction of amino acids absorbed varied considerably. Values ranged from -0.25 to +0.07 for arginine; or -0.36 to +1.12 for methionine. A major factor is undoubtedly physiological state, the absorption of amino acids relative to requirements, and associated changes in arterial concentration (Reynolds, 2002). Thus in the study by Reynolds et al. (2001), for the ratio net hepatic removal/portal absorption, there is a striking difference between lactation and the dry period (Table 12.1). In contrast, simply varying the amino acid input results in little appreciable change in this ratio (Caton et al., 2001).

Table 12.1. Ratio of the net removal of amino acids by the liver to their net release into the portal vein. Results from studies in lactating and dry cows by Reynolds et al. (2001) and abomasal infusion studies of Caton et al. (2001). The ratios have been calculated from the sum of the essential (valine, isoleucine, leucine, methionine, lysine, threonine, phenylalanine, tryptophan and histidine) amino acids (EAA) and the non-essential (arginine, ornithine, citrulline, alanine, glycine, serine, aspartate, asparagine, glutamate, glutamine, proline and tyrosine) amino acids (NEAA).

\begin{tabular}{lcccc}
\hline Reynolds et al. & \multicolumn{3}{c}{ Dry } \\
& \multicolumn{3}{c}{ Lactating } \\
\cline { 2 - 5 } & Low intake & High intake & Low intake & High Intake \\
\hline EAA & 0.73 & 0.55 & 0.13 & 0.08 \\
NEAA & 1.43 & 1.26 & 0.67 & 0.66 \\
& & & & \\
Caton et al. & Control & + EAA & Control & + Casein \\
(2001) & 0.32 & 0.38 & 0.41 & 0.39 \\
EAA & 0.88 & 0.91 & 1.07 & 1.04 \\
NEAA & & & & \\
\hline
\end{tabular}

\section{MINERALS}

There have been few reports of the net exchange of minerals across the PDV or liver. The probable 
reasons for this are illustrated in work by

Reynolds et al. (1991a). The authors studied exchange of $\mathrm{Na}, \mathrm{K}, \mathrm{Ca}, \mathrm{P}$ and $\mathrm{Mg}$ in dairy cattle, first in lactating animals and then in a dietary study comparing hay and concentrate diets. Portal vein and arterial concentration differences were at best of the order of $1-3 \%$ of the arterial concentration, and frequently less than $1 \%$. It is difficult to get adequate precision with such small differences. For portal-hepatic vein differences, relative to portal concentrations, the differences were generally even smaller, suggesting little net metabolism of plasma minerals by the liver. There is a slight improvement with measurement of absorption into the mesenteric vein when differences can be up to 6-7 \%. There is a further complication with $\mathrm{Na}$ and $\mathrm{P}$, since large amounts of these ions are secreted into the rumen in saliva. Thus Na was apparently absorbed in amounts many-fold greater than the dietary intake.

Nevertheless some consistent findings were demonstrable. For $\mathrm{Mg}$, in the dietary study, net PDV release was about $20 \%$ of intake, and as earlier evidence has suggested, was almost entirely from the 'stomach' tissues. In lactation, net PDV release was 17\% of intake, from a much higher amount. For $\mathrm{Ca}$ in the dietary study, net PDV release was $16 \%$ of intake, and in lactation $17 \%$. For $\mathrm{K}$, net PDV release in the dietary study was $50-60 \%$ of intake, and in lactation, $66 \%$. For both these minerals, post-stomach tissues (probably small intestine) accounted for most of the absorption (80$90 \%)$

\section{HORMONES}

A selection of papers relating to hormones produced and metabolised in the PDV of cattle is shown in Table 12.2.

Table 12.2. Some values in cattle for arterial concentrations, rates of net secretion into the portal vein and removal by the liver of insulin, IGF-1 (Insulin-like growth factor-1), glucagon, GLP (glucagon-like peptide 1), and CCK-8 (choleocystokinin) in various physiological conditions.

\begin{tabular}{|c|c|c|c|c|c|c|}
\hline Authors & Condition & Hormone. & $\begin{array}{l}\text { Arterial } \\
\text { concentra } \\
\text { tion }(\mathrm{pM})\end{array}$ & $\begin{array}{l}\text { PDV } \\
\text { release } \\
\text { nmol }^{-1}\end{array}$ & $\begin{array}{l}\text { liver } \\
\text { removal } \\
\text { nmol } h^{-1}\end{array}$ & $\begin{array}{l}\text { \% supply } \\
\text { extracted } \\
\text { by liver }\end{array}$ \\
\hline \multirow{2}{*}{$\begin{array}{l}\text { Reynolds et } \\
\text { al. (1992b) }\end{array}$} & Beef steers (Basal) & Insulin & 193.5 & 28.4 & 8.2 & 7.6 \\
\hline & + butyrate $\left(25 \mathrm{mmol} \mathrm{h}^{-1}\right.$ & & 208.1 & 29.4 & 9.1 & 7.5 \\
\hline \multirow[t]{2}{*}{$\begin{array}{l}\text { Lapierre et al. } \\
\text { (1992) }\end{array}$} & $\begin{array}{l}\text { Beef steers (High } \\
\text { intake) }\end{array}$ & Insulin & 177.9 & 28.8 & 4.0 & 2.8 \\
\hline & & $\begin{array}{l}\text { Glucagon } \\
\text { IGF-1 }\end{array}$ & $\begin{array}{l}114.7 \\
22.3(n M)\end{array}$ & $\begin{array}{l}11.7 \\
-225\end{array}$ & $\begin{array}{l}6.1 \\
61.4\end{array}$ & 8.6 \\
\hline \multirow{2}{*}{$\begin{array}{l}\text { Krehbiel et al. } \\
\text { (1992) }\end{array}$} & Beef steers (Basal) & Insulin & 253.7 & 22.2 & 26.2 & 19.2 \\
\hline & + butyrate $(50-250$ & & 266.4 & 27.1 & 5.1 & 3.3 \\
\hline
\end{tabular}




\begin{tabular}{|c|c|c|c|c|c|c|}
\hline Casse et al. & lactating cows (basal) & Insulin & 191.1 & 30.5 & 21.3 & 5.4 \\
\hline & $\begin{array}{l}\text { +propionate }(150 \mathrm{mmol} \\
\left.\mathrm{h}^{-1}\right)\end{array}$ & & 199.3 & 45.5 & 15.9 & 3.8 \\
\hline & lactating cows (basal) & Glucagon & 117.9 & 29.8 & 20.4 & 8.6 \\
\hline & $\begin{array}{l}+ \text { propionate }(150 \mathrm{mmol} \\
\left.\mathrm{h}^{-1}\right)\end{array}$ & & 123.4 & 40.5 & 38.5 & 14.2 \\
\hline $\begin{array}{l}\text { Lapierre et al. } \\
\text { (2000) }\end{array}$ & $\begin{array}{l}\text { beef steers } \\
\text { low intake }(0.6 \mathrm{M})\end{array}$ & Insulin & 54.1 & 12.9 & 4.4 & 14.6 \\
\hline & medium intake (M) & & 61.0 & 18.0 & 9.1 & 23.3 \\
\hline & high intake(1.6M) & & 104.6 & 27.9 & 13.1 & 18.9 \\
\hline & low & glucagon & 23.0 & 1.7 & 0.0 & \\
\hline & medium & & 28.7 & 3.7 & 0.3 & 2.1 \\
\hline & high & & 34.4 & 5.5 & 1.4 & 7.5 \\
\hline & low & IGF-1 & 23.9 & -29.4 & 51.0 & \\
\hline & medium & & 32.8 & 84.3 & -129.8 & \\
\hline & high & & 31.8 & 326.8 & 425.4 & \\
\hline Benson and & Dairy Cows & & & & & \\
\hline Reynolds & 55d (early lactation); & & & & & \\
\hline (2001) & $\begin{array}{l}110 \mathrm{~d} \text { (medium lactation } \\
\text { early, basal }\end{array}$ & Insulin & 59.4 & 38.5 & 20.8 & 12.4 \\
\hline & $\begin{array}{l}\text { early, unsaturated fatty } \\
\text { acids (UFA) }\end{array}$ & & 53.4 & 36.4 & 18.8 & 10.4 \\
\hline & medium, basal & & 87.7 & 43.3 & 21.1 & 9.8 \\
\hline & medium, UFA & & 65.9 & 39.2 & 18.1 & 9.9 \\
\hline & early, basal & $\begin{array}{l}\text { gut } \\
\text { glucagon }\end{array}$ & 337 & 2 & -23.8 & \\
\hline & early, UFA & & 385 & -4.6 & -37.8 & \\
\hline & medium, basal & & 264 & -4.8 & -30.3 & \\
\hline & medium, UFA & & 342 & 2.9 & -51 & \\
\hline & early, basal & $\begin{array}{l}\text { pancreatic } \\
\text { glucagon }\end{array}$ & 87.2 & 25.9 & 6.7 & 2.3 \\
\hline & early, UFA & & 92.5 & 30.6 & 15.6 & 4.9 \\
\hline & medium, basal & & 104.5 & 35 & 3.9 & 0.5 \\
\hline & medium, UFA & & 121 & 42.6 & 7.6 & 2.2 \\
\hline & early, basal & GLP & 54.3 & -3.9 & 1.5 & \\
\hline & early, UFA & & 59.1 & -5.7 & 2.2 & \\
\hline & medium, basal & & 48.1 & -1.8 & 1.1 & \\
\hline & medium, UFA & & 55.4 & -5.5 & 1.1 & \\
\hline & early, basal & CCK-8 & 25.7 & 8 & 1.6 & 2.8 \\
\hline & early, UFA & & 24.3 & 5.2 & 0.9 & 2.9 \\
\hline & medium, basal & & 19.9 & 10.1 & 5.7 & 8.5 \\
\hline & medium, UFA & & 18.2 & 8.8 & 4.9 & 10.4 \\
\hline
\end{tabular}

Although insulin is still perhaps the hormone most studied, there is increasing information on glucagon, and there is increasing discrimination between pancreatic and gut-derived glucagons. Discrimination between various glucagon-like hormones emphasises the importance of specific assays. The apparent net release of gut glucagon by the liver may reflect release of glucagon fragments and may indicate that assay for fragments will be desirable. Apart from data in the first 

rate of net secretion by the PDV, as was suggested for insulin in the first edition of this Chapter. The data also emphasise the importance of the liver in extracting hormones and thereby affecting peripheral concentrations.

\section{CONCLUSIONS}

The continuing extensive use of animals surgically-prepared with gastrointestinal and hepatic venous catheters has demonstrated that the technique is now fairly reliable and there is increasing understanding of limitations and how they may be overcome. In the earlier edition, doubt was expressed whether the technique would be sufficiently sensitive to look at variations of diet. For many purposes at least, such doubts were not justified. We may expect to see increasing use of the technique as a tool for future investigations of ruminant metabolism. However, for many metabolites the limitations of net flux measurements encourage the combined use of multicatheterization and isotopic labelling techniques, which can provide much greater insight into the nuances of PDV metabolism.

\section{REFERENCES}

Alio, A., Theurer, C.B., Lozano, O., Huber, J.T., Swingle, R.S., Delgardo-Elorduy, A., Cuneo, P., DeYoung, D. and Webb, K.E. Jr. (2000) Splanchnic nitrogen metabolism by growing beef steers fed diets containing sorghum grain flaked at different densities. Journal of Animal Science 78, $1355-1363$.

Benson, J.A. and Reynolds, C.K. (2001) Effects of abomasal infusion of long-chain fatty acids on splanchnic metabolism of pancreatic and gut hormones in lactating dairy cows. Journal of Dairy Science 84, 1488-1500.

Benson, J.A., Reynolds, C.K., Aikman, P.C., Lupoli, B. and Beever, D.E. (2002) Effects of abomasal long chain fatty acid infusion on splanchnic energy metabolism in lactating dairy cows. Journal of Dairy Science 85, 1804-1814.

Bergman, E.N. (1975) Production and utilisation of metabolites by the alimentary tract as measured in portal and hepatic blood. In: McDonald, I.W. and Warner, A.C.I. (eds) Digestion and Metabolism in the Ruminant. The University of New England, Armidale, Australia, pp 292305.

Bergman, E.N., Havel, R.J., Wolff, B.M. and Bohmer, T. (1971) Quantitative studies of the metabolism of chylomicron triglycerides and cholesterol by liver and extra-hepatic tissues of sheep and dogs. Journal of Clinical Investigation 50, 1831-1839.

Bergman, E.N. and Wolff, J.E. (1971) Metabolism of volatile fatty acids by liver and portal-drained viscera in sheep. American Journal of Physiology 221, 586-592.

Berthiaume, R., Debreuil, P., Stevenson, M., McBride, B.W. and Lapierre, H. (2001) Intestinal disappearance and mesenteric and portal appearance of amino acids in dairy cows fed ruminally protected methionine. Journal of Dairy Science 84, 194-203.

Blouin, J.P., Bernier, J.F., Reynolds, C.K., Lobley, G.E., Dubreuil, P. and Lapierre, H. (2002) 
Effect of diet quality on splanchnic fluxes

of nutrients and hormones in lactating cows. Journal of Dairy Science 85, 2618-2630.

Bruckental, I., Huntington, G.B., Baer, C., Kirk, J. and Erdman, R.A. (1997). The effect of abomasal infusion of casein and recombinant somatotropin hormone injection on nitrogen balance and amino acid fluxes in portal-drained viscera and net hepatic and total splanchnic blood in Holstein steers Journal of Animal Science 75, 1119-1129.

Casse, E.A., Rulquin, H. and Huntington, G.B. (1994) Effect of mesenteric vein infusion of propionate on splanchnic metabolism in Primiparous Holstein cows. Journal of Dairy Science 77, 3296-3303.

Caton, J.S., Reynolds, C.K., Bequette, B.J., Lupoli, B., Aikman, P.C. and Humphries, D.J. (2001) Effects of abomasal casein or essential amino acid infusions on splanchnic leucine and phenylalanine metabolism in lactating cows. Journal of Dairy Science, Supplement 1 79, 362.

Drost, C.J. (1978) Vessel diameter-independent volume flow measurement using ultrasound. Proceedings of the San Diego Biomedical Symposium 17, 299 -302.

Durand D., Bauchart, D., Laplaud, P.M., Lefaivre, J. and Chapman, M.J. (1990) Importance of the portal venous pathway to the transport of intestinal triglyceride-rich lipoproteins in the preruminant calf. Reproduction, Nutrition et Developpement, Supplement 2, 228S.

Early, R.J., Thompson, J.R., Christopherson, R.J. and Sedgwick, G.W. (1987) Blood branchedchain amino acid and $\alpha$-keto acid concentrations and net exchange across the portal-drained viscera and hindlimb of fed and fasted ruminants Canadian Journal of Animal Science 67, 1011-1020.

Eisemann, J.H. and Nienaber, J.A. (1990) Tissue and whole body oxygen uptake in fed and fasted steers. British Journal of Nutrition 64, 399-411.

Eisemann, J.H. and Huntington, G.B. (1994) Metabolite flux across portal-drained viscera, liver, and hindquarters of hyperinsulinemic, euglycemic beef steers. Journal of Animal Science 72, 2919-2929.

Eisemann, J.H., Huntington, G.B. and Catherman, D.R. (1997) Insulin sensitivity and responsiveness of portal-drained viscera, liver, hindquarters, and whole body of beef steers weighing 275 or 490 kilograms. Journal of Animal Science 75, 2084-2091.

France, J, Hanigan, M.D., Reynolds, C.K., Dijkstra, J., Crompton, L., Maas, J.A., Bequette, B.J., Metcalf, J.A., Lobley, J.E., Macrae, J.C. and Beever, D.E. (1999) An isotope dilution model for partitioning leucine uptake by the liver of the lactating dairy cow. The Journal of Theoretical Biology 198, 121-133.

Freetly, H.C. and Ferrell, C.L. (1998) Net flux of glucose, glucose, lactate, Volatile fatty acids, and Nitrogen metabolites across the portal-drained viscera and liver of pregnant ewes Journal of Animal Science 76, 3133-3145.

Freetly, H.C. and Ferrell, C.L. (2000) Net flux of nonesterified fatty acids, cholesterol, triacylglycerol, and glycerol across the portal-drained viscera and liver of pregnant ewes Journal of Animal Science 78, 1380-1388.

Goetsch, A.L. and Ferrell, C.L. (1995) Effects of dietary maize level on net flux across splanchnic tissues of oxygen and nutrients in wethers consuming ad libitum different forages. Animal Science 61, 43-55.

Goetsch, A.L., Ferrell, C.L. and Freetly, H.C. (1994) Effects of different supplements on splanchnic oxygen consumption and net fluxes of nutrients in sheep consuming bromegrass (Bromus inermis) hay ad libitum. British Journal of Nutrition 72, 701-712.

Goetsch, A.L., Patil, A.R., Galloway, D.L., Kouakou, B., Wang, Z.S., Park, K.R. and Rossi, J.E. (1997a) Net flux of nutrients across splanchnic tissues in wethers consuming grasses of different sources and physical forms ad libitum. British Journal of Nutrition 77, 769-781.

Goetsch, A.L., Patil, A.R., Galloway, D.L. Sr, Wang, Z.S., Kouakou, B., Park, K.K. and Rossi, J.E. (1997b) Oxygen consumption by splanchnic tissues in wethers consuming ad libitum different proportions of bermudagrass and ryegrass-wheat. Archives of Animal Nutrition 50, 1-11.

Goetsch, A.L., Patil, A.R., Wang, Z.S., Park, K.K., Galloway, D.L., Sr, Rossi, J.E. and Kouakou, B. 
(1997c) Net flux of nutrients across

splanchnic tissues in wethers consuming grass hay with or without corn and alfalfa. Animal Feed Science Technology 66, 271-282.

Goetsch, A.L., Patil, A.R., Wang, Z.S., Park, K.K., Galloway, D.L. Sr, Rossi, J.R. and Kouakou, B. (1997d) Net flux of nutrients across splanchnic tissues in wethers consuming bermudagrass or ryegrass-wheat supplemented with rumen undegradable protein. Small Ruminant Research 25, $119-128$

Gross, K.L., Harmon, D.L. and Avery, T.B. (1988) Net portal flux in steers fed diets containing wheat and sorghum grain alone or in combination. Journal of Animal Science 66, 543-551.

Gross, K.L., Harmon, D.L. and Avery, T.B. (1990) Portal-drained visceral flux of nutrients in lambs fed alfalfa or maintained by total intragastric infusion. Journal of Animal Science 68, 214-221.

Habel, R.E. (1992) Guide to the dissection of domestic ruminants. Ithaca, New York

Han, X.T., Noziere, P., Remond, D., Chabrot, J. and Moreau, M. (2002) Effects of nutrient supply and dietary bulk on $\mathrm{O}_{2}$ uptake and nutrient net fluxes across rumen, mesenteric- and portaldrained viscera in ewes. Journal of Animal Science 80, 1362-1375.

Hanigan, M.D., Crompton, L.A., Reynolds, C.K., Wray-Cohen, D., Lomax, M.A. and France, J. (2004) An integrative model of amino acid metabolism in the liver of the lactating dairy cow. The Journal of Theoretical Biology 228, 271-289.

Harmon, D.L., Richards, K.C., Swanson, J.A., Howell, J.C, Matthews, J.C., True, A.D., Huntingdon, G.B., Gahr, S.A. and Russell, R.W. (2001) Influence of ruminal or post-ruminal starch on visceral glucose metabolism in steers. In: Chwalibog, A. and Jakobsen, K. (eds) Energy Metabolism in Farm Animals, EAAP publication no 103. Wageningen Press, Wageningen, Netherlands, pp 273.

Heath, T.J. and Perkins, N.R. (1985) Effect of development of the ovine forestomachs in the anatomy of portal vessels and on the intrahepatic distribution of portal blood. Research in Veterinary Science 39, 216-221.

Huntington, G.B. (1989) Hepatic urea synthesis and site and rate of urea removal from blood of beef steers fed alfalfa hay or a high concentrate diet. Canadian Journal of Animal Science 69, 215-223.

Huntington, G.B. and Tyrrell, H.F. (1985) Oxygen consumption by portal-drained viscera of cattle: comparison of analytical methods and relationships to whole body oxygen consumption. Journal of Dairy Science 68, 2727-2731.

Huntington, G.B., Varga, G.A., Glenn, B.P. and Waldo, D.R. (1988) Net absorption and oxygen consumption by Holstein steers fed alfalfa or orchardgrass silage at two equalised intakes Journal of Animal Science 66, 1292-1302.

Huntington, G.B., Reynolds, C.K. and Stroud, B. (1989) Techniques for measuring blood flow in the splanchnic tissues of cattle. Journal of Dairy Science 72, 1583-1595.

Huntington, G.B., Eisemann, J.H. and Whitt, J.M. (1990) Portal blood flow in beef steers. Comparison of techniques and relation to hepatic flow, cardiac output and oxygen uptake. Journal of Animal Science 68, 1666-1673.

Huntington, G.B., Zetina, E.J., Whitt, J.M. and Potts, W. (1996) Effects of dietary concentrate level on nutrient absorption, liver metabolism, and urea kinetics of beef steers fed isonitrogenous and isoenergetic diets. Journal of Animal Science 74, 908 -916.

Janes, A.N., Weekes, T.E.C. and Armstrong, D.G. (1985) Absorption and metabolism of glucose by the mesenteric-drained viscera of sheep fed on dried-grass or ground maize-based diets. British Journal of Nutrition 54, 449-458.

Krehbiel, C.R., Harmon, D.L. and Schneider, J.E. (1992) Effect of increasing ruminal butyrate on portal and hepatic nutrient flux in steers. Journal of Animal Science 70, 904-914.

Kreikemeier, K.K. and Harmon, D.L. (1995) Abomasal glucose, maize starch and maize dextrin infusions in cattle: small intestinal disappearance, net portal flux and ileal oligosaccharide flow British Journal of Nutrition 73, 763-772.

Kristensen, N.B., Gabel, G., Pierzynowski, S.G. and Danfaer, A. (2000a) Portal recovery of shortchain fatty acids infused into the temporarily-isolated and washed reticulo-rumen of sheep. 
British Journal of Nutrition 84, 477-482.

Kristensen, N.B., Pierzynowski, S.G. and Danfaer, A. (2000b) Portal-drained visceral metabolism of 3-bydroxy butyrate in sheep. Journal of Animal Science 78, 2223- 2228.

Lapierre, H. and Lobley, G.E. (2001) Nitrogen Recycling in the Ruminant: A Review. Journal of Dairy Science Supplement 84, E223-E236.

Lapierre, H., Reynolds, C.K., Elsasser, T.H., Gaudreau, P., Brazeau, P. and Tyrrell, H.F. (1992) Effects of growth hormone-releasing factor and feed intake on energy metabolism in growing beef steers: Net hormone metabolism by portal-drained viscera and liver. Journal of Animal Science 70, 742-751.

Lapierre, H., Bernier, J.F., Dubreuil, P., Reynolds, C.K., Farmer, C., Ouellet, D.R. and Lobley, G.E. (2000) The effect of feed intake level on splanchnic metabolism in growing beef steers. Journal of Animal Science 78, 1084-1099.

Lindsay, D.B. and Oddy, V.H. (1985) Pregnancy toxaemia in sheep - A review. In: Cumming, R.B. (ed.) Recent Advances in Animal Nutrition in Australia in 1985. University of New England Publishing Unit, Section 32.

Lobley, G.E. (1993) Protein metabolism and turnover. In: Forbes, J.M. and France, J. (eds) Quantitative Aspects of Ruminant Digestion and Metabolism. CAB International, Wallingford, UK, pp. 313-339.

Lobley, G.E., Milano, G.D. and van der Walt, J.G. (2000) The liver: integrator of nitrogen metabolism. In: Cronje, P.B (ed.) Ruminant Physiology. Digestion, Metabolism, Growth and Reproduction. CABI Publishing, Wallingford, UK, pp.149-168.

Lozano, O., Theurer, C.B., Alio, A., Huber, J.T., Delgado-Elorduy, A., Cuneo, P., De Young, D., Sadik, M. and Swingle, R.S. (2000) Net absorption and hepatic metabolism of glucose, Llactate, and volatile fatty acids by steers fed diets containing sorghum grain processed as dryrolled or steam-flaked at different densities. Journal of Animal Science 78, 1364-1371.

MacRae, J.C., Bruce, L.A., Brown, D.S. and Calder, G. (1997a) Amino acid use by the gastrointestinal tract of sheep given lucerne forage American Journal of Physiology 273, G1200-G1207.

MacRae, J.C., Bruce, L.A., Brown, D.S., Farningham, D.A.H. and Franklin, M. (1997b) Absorption of amino acids from the intestine and their net flux across the mesenteric- and portal-drained viscera of lambs. Journal of Animal Science 75, 3307-3314.

Maltby, S.A., Reynolds, C.K., Lomax, M.A. and Beever, D.E. (1993) The effect of increased absorption of ammonia and arginine on splanchnic metabolism of beef steers. Animal Production 56, 462.

Milano, G.D., Hotston-Moore, A. and Lobley, G.E. (2000) Influence of hepatic ammonia removal on ureagenesis, amino acid utilisation and energy metabolism in the ovine liver. British Journal of Nutrition 83, 307-315.

Morris, P.G, Dominick, J.O., Coxon, R., Bachelard, H.S., Moriarty, K.T., Greenhaff, P.L., and McDonald, I.A. (1994) Nuclear magnetic resonance spectroscopy as a tool to study carbohydrate metabolism. Proceedings of the Nutrition Society 53, 335-343.

Noziere, P., Martin, C., Rémond, D., Kristensen, N.B., Bernard, R. and Doreau, M. (2000) Effect of composition of ruminally-infused short-chain fatty acids on net flux of nutrients across portaldrained viscera in underfed ewes. British Journal of Nutrition 83, 521-531.

Ortigues, I., Martin, C and Durand, D. (1996) Circadian changes in net nutrient flows across the portal-drained viscera, the liver and hindquarters in preruminant calves. Journal of Animal Science 74, 895-907.

Park, K.K., Goetsch, A.L., Johnson, Z.B. and Rossi, J.E. (1997) Temporal pattern of nutrients across splanchnic tissues in wethers consuming different forages. Small Ruminant Research 25, 107-118.

Patil, A.R., Goetsch, A.L., Park, K.K., Kouakou, B., Galloway, D.L., Sr. and Johnson, Z.B. (1995) Influence of grass source on net flux of nutrients across splanchnic tissues in sheep with restricted intake. Archives of Animal Nutrition 48, 257-269. 
Patil, A.R., Goetsch, A.L., Park, K.K.,

Kouakou, B., Galloway, D.L.Sr. and Johnson, Z.B. (1996) Influence of grass source and legume level on net flux of nutrients across splanchnic tissues in sheep. Small Ruminant Research 22, 111-122.

Pell J.M., Caldarone, E.M. and Bergman, E.N. (1986) Leucine and $\alpha$-ketoisocaproate metabolism and interconversions in fed and fasted sheep. Metabolism 35, $1005-1016$.

Pethick, D.W., Lindsay, D.B., Barker, P.J. and Northrop, A.N. (1981) Acetate supply and utilisation by the tissues of sheep in vivo. British Journal of Nutrition 46, 97-110.

Rémond, D., Chaise, J.P., Delval, E. and Poncet, C. (1993) Net flux of metabolites across the ruminal wall of sheep fed twice a day with orchardgrass hay. Journal of Animal Science 71, 2529-2538.

Rémond, D., Ortigues-Marty, L., Isserty, A. and Lefaivre, J. (1998) Technical note: Measuring portal blood in sheep using an Ultrasonic Transit Time Flow Probe Journal of Animal Science 76, 2712-2716.

Reynolds, C.K. (1995) Quantitative aspects of liver metabolism in ruminants. In: Cronje, P.B (ed) Ruminant Physiology. Digestion, Metabolism, Growth and Reproduction. CABI Publishing, Wallingford, UK, 351-371.

Reynolds, C.K. (2002) Economics of visceral energy metabolism in ruminants - toll keeping or internal revenue service? Journal of Animal Science 80 Supplement 2, E74-E84.

Reynolds, C.K. and Huntington, G.B. (1988) Partition of portal-drained visceral net flux in beef steers. 1. Blood flow and net flux of oxygen, glucose and nitrogenous compounds across stomach and post-stomach tissues. British Journal of Nutrition 60, 539-551.

Reynolds, C.K. and Tyrrell, H.F. (1991) Effects of mesenteric vein L-alanine infusion on liver metabolism in beef heifers fed on diets differing in forage:concentrate ratio. British Journal of Nutrition 66, 437-450.

Reynolds, C.K., Huntington, G.B., Tyrrell, H.F. and Reynolds, P.J. (1986) Splanchnic tissue and whole animal oxygen consumption by lactating Holstein cows. Journal of Dairy Science 69 Supplement 1, 193.

Reynolds, C.K., Huntington, G.B., Tyrrell, H.F. and Reynolds, P. (1988a) Net metabolism of volatile fatty acids, D-ß-hydroxybutyrate, non-esterified fatty acids, and blood gases by portaldrained viscera and liver of lactating Holstein cows. Journal of Dairy Science 71, 2395-2405.

Reynolds, C.K., Huntington, G.B., Tyrrell, H.F. and Reynolds, P. (1988b) Net portal-drained visceral and hepatic metabolism of glucose, L-lactate, and nitrogenous compounds in lactating Holstein cows. Journal of Dairy Science 71, 1803-1812.

Reynolds, C.K., Huntington, G.B., Tyrrell, H.F. and Reynolds, P.J. (1991a) Net absorption of macrominerals by portal-drained viscera from lactating Holstein cows and beef steers Journal of Dairy Science 74, 450-459.

Reynolds, C.K., Tyrrell, H.F. and Reynolds, P.J. (1991b) Effects of diet forage-to-concentrate ration and intake on energy metabolism in growing beef heifers: whole body energy and nitrogen balance and visceral heat production. Journal of Nutrition 121, 994-1003.

Reynolds, C.K., Tyrrell, H.F. and Reynolds, P.J. (1991c) Effects of diet forage-to-concentrate ration and intake on energy metabolism in growing beef heifers: net nutrient absorption by visceral tissues Journal of Nutrition 121, 1004-1015.

Reynolds, C.K., Lapierre, H., Tyrrell, H.F., Elsasser, T.H., Staples, R.C., Gaudreau, P. and Brazeau, P. (1992a) Effects of growth hormone-releasing factor and intake on energy metabolism in growing beef steers: Net nutrient metabolism by portal-drained viscera and liver. Journal of Animal Science 70, 752-763.

Reynolds, C.K., Tyrrell, H.F. and Armentano, L.E. (1992b) Effects of mesenteric vein n-butyrate infusion on liver metabolism by beef steers. Journal of Animal Science 70, 2250-2261.

Reynolds, C.K., Casper, D.P., Harmon, D.L. and Milton, C.T. (1992c) Effect of CP and ME intake on visceral nutrient metabolism in beef steers. Journal of Animal Science 70 Supplement 1, 315.

Reynolds, C., Lapierre, H., Tyrrell, H., Elsasser, T., Casper, D., Gaudreau, P. and Brazeau, P. 
(1993a) Intake and growth hormone- releasing factor (GRF) affect visceral metabolism of VFA in growing beef steers. Journal of Animal Science 71 supplement 1, 270.

Reynolds, C.K., Tyrrell, H.F. and Reynolds, P.J. (1993b) Effects of forage-to-concentrate ratio and intake on net visceral metabolism of VFA in growing beef heifers. Journal of Dairy Science 76 supplement 1, 283.

Reynolds, C.K., Huntington, G.B. and Tyrrell, H.F. (1994a) Effects of feeding maize grain harvested at 2 stages of maturity on net nutrient metabolism by splanchnic tissues of lactating dairy cows. Animal Production 58, 433.

Reynolds, C.K., Harmon, D.L., Prior, R.L. and Tyrrell, H.F. (1994b) Effects of mesenteric vein 1alanine infusion on liver metabolism of organic acids by beef heifers fed diets differing in forage: concentrate ratio. Journal of Animal Science 72, 3196-3206.

Reynolds, C.K., Crompton, L.A., Firth, K., Beever, D., Sutton, J., Lomax, M., Wray-Cahen, D., Metcalfe, J., Chettle, E., Bequette, B., Backwell, C., Lobley, G. and MacRae, J. (1995) Splanchnic and milk protein responses to mesenteric vein infusion of 3 mixtures of amino acids in lactating dairy cows. Journal of Animal Science 73 Supplement 1, 274.

Reynolds, C.K., Humphries, D.J., Cammell, S.B., Benson, J., Sutton, J.D. and Beever, D.E. (1998a) Effects of abomasal wheat starch infusion on splanchnic metabolism and energy balance of lactating dairy cows. In: McCracken, K.J., Unsworthand, E.F. and Wylie, A.R.G (eds) Energy Metabolism of Farm Animals, Proceedings of the $14^{\text {th }}$ Symposium on Energy metabolism. CAB International, Wallingford, UK, pp. 39-42.

Reynolds, C.K., Humphries, D.J., Benson, J.A. and Beever, D.E. (1998b) Effects of abomasal starch infusion on splanchnic metabolism and milk production in dairy cows. Journal of Animal Science 76 Supplement 1, 310.

Reynolds, C.K., Lupoli B., Aikman, P.C., Humphries, D.J., Crompton, L.A., Sutton, J.D., France, J., Beever, D.E. and MacRae, J.C. (1999) Effects of abomasal casein or essential amino acid infusions on splanchnic metabolism in dairy cows. Journal of Animal Science 77 Supplement 1, 266.

Reynolds, C.K., Lupoli, B., Aikman, P.C., Benson, J.A., Humphries, D.J., Crompton, L.A., Sutton, J.D., France, J., Beever, D.E. and MacRae, J.C. (2000) The effects of diet protein level and abomasal amino acid infusions on splanchnic metabolism in lactating dairy cows. Journal of Animal Science 83 Supplement 1, 299.

Reynolds, C.K., Bequette, B.J., Caton, J.S., Humphries, D.J., Aikman, P.C., Lupoli, B. and Sutton, J.D. (2001) Effects of intake and lactation on absorption and metabolism of leucine and phenyl alanine by splanchnic tissues of dairy cows. Journal of Dairy Science 84 Supplement 1, 362.

Reynolds, C.K., Aikman, P.C., Lupoli, B., Humphries, D.J. and Beever, D.E. (2003a) Splanchnic metabolism of dairy cows during the transition from late gestation through early lactation. Journal of Dairy Science 86, 1201-1217.

Reynolds, C. K., Benson, J.A., Aikman, P.C., Lupoli, B., Hanigan, M.D., Beever, D.E. and MacRae, J.C. (2003b) Effects of diet forage:concentrate ratio on splanchnic nutrient metabolism in lactating dairy cows. Journal of Dairy Science 86 supplement 1, 219.

Rook, J.A.F. (1976) Nutritional influences on milk quality. In: Swan, H. and Broster, W.H. (eds) Principles of Cattle Production Chapter 10. pp. 221 -237 (reference on pp 224-5)

Seal, C.J. and Parker, D.S. (1994) Effect of intraruminal propionic acid infusion on metabolism of mesenteric and portal-drained viscera in growing steers fed a forage diet. I.Volatile fatty acids, glucose and lactate. Journal of Animal Science 72, 1325-1334.

Seal, C.J. and Reynolds, C.K. (1993) Nutritional implications of gastrointestinal and liver metabolism in ruminants. Nutrition Research Reviews 6, 185-208.

Seal, C.J., Parker, D.S. and Avery, P.J. (1992) The effect of forage and forage-concentrate diets on rumen fermentation and metabolism of nutrients by the mesenteric and portal-drained viscera of growing steers. British Journal of Nutrition 67, 355-370.

Tagari, H. and Bergman, E.N. (1978) Intestinal disappearance and portal blood appearance of amino acids in sheep. Journal of Nutrition 108, 790-803. 
Taniguchi, K., Huntington, G.B. and Glenn,

B.P. (1995) Net nutrient flux by visceral tissues of beef steers given abomasal and ruminl infusions of casein and starch. Journal of Animal Science 73, 236-249.

Theurer, C.B., Huntingdon, G.B., Huber, J.T., Swingle, R.S. and Moore, J.A. (2002) Net absorption and utilisation of nitrogen compounds across ruminal, intestinal and hepatic tissues of growing beef steers fed dry-rolled or steam-flaked sorghum grain. Journal of Animal Science 80, 525532.

Van Bruchem, J., Voigt, J., Lammers-Wienhoven, S.C.W., Schonhusen, U., Ketelaars, H. and Tamminga, S. (1997) Secretion and reabsorption of endogenous protein along the small intestine of sheep: estimates derived from ${ }^{15} \mathrm{~N}$ dilution of plasma non-protein-N. British Journal of Nutrition 77, 273-286.

Van der Walt, J.G., Baird, G.D. and Bergman, E.N. (1983) Tissue glucose and lactate metabolism and interconversions in pregnant and lactating sheep. British Journal of Nutrition 50, 267-280.

Weekes, T.E.C. and Webster, A.J.F. (1975) Metabolism of propionate in the tissues of the sheep gut. British Journal of Nutrition 33, 425-438.

Yu, F., Bruce, L.A., Calder, A.G., Milne, E., Coop, R.L., Jackson, F., Horgan, G.W. and MacRae, J.C. (2000) Subclinical infection with the nematode Trichostrongylus colubriformis increases gastrointestinal tract leucine metabolism and reduces availability of leucine for other tissues. Journal of Animal Science 78, 380-390. 


\section{$\underline{\text { Legends to Figures }}$}

Fig. 12.1. The siting of catheters in splanchnic studies. More detailed descriptions of the vascular anatomy of the bovine intestines (Habel, 1992) and liver (Seal and Reynolds, 1993) are provided in other texts.

Fig. 12.2. Compartmental models for analysis of glucose/lactate interconversions. (a) Full solution requires infusions of both labelled glucose and lactate (b) Simplified model (see text) requiring infusion only of labelled glucose.

Fig. 12.3. Energy use by portal-drained viscera and liver as a function of digestible energy intake in sheep and cattle. (a) Portal oxygen consumption in cattle. $y=0.1302 x+2.0497\left(R^{2}=0.908\right)$. (b) Hepatic oxygen consumption in cattle. $y=0.1427 x+0.5373\left(R^{2}=0.956\right)$. (c) Portal oxygen consumption in sheep. $\mathrm{y}=0.0802 \mathrm{x}+0.6464\left(\mathrm{R}^{2}=0.569\right)$. (d) Hepatic oxygen consumption in sheep $\mathrm{y}=0.0852 \mathrm{x}+0.4517\left(\mathrm{R}^{2}=0.393\right)$. Data for cattle taken from Benson et al. $(2002)$; Casse et al. (1994); Caton et al. (2001); Bruckenthal et al. (1997); Eisemann and Nienaber (1990); Huntington and Tyrrell (1985); Huntington et al. (1988); Maltby et al. (1993); Reynolds et al. (1986; 1988a; 1991b; 1992 a, b, c; 1994a; 1995; 1998 a, b; 1999; 2000; 2001; 2003 a, b); Taniguchi et al. (1995). Data for sheep taken from Goetsch and Ferrell (1995); Goetsch et al. (1997 a, b, c, d); Patil et al. (1995, 1996); Park et al. (1997); Lindsay (unpublished).

Fig. 12.4. Relation in sheep between amino acids absorbed from the small intestine and appearing in (a) portal vein $\square . \mathrm{y}=0.7193 \mathrm{x}+13.226\left(\mathrm{R}^{2}=0.7397\right)(\mathrm{b})$ mesenteric vein. $\bullet \mathrm{y}=0.4121 \mathrm{x}+$ $10.985\left(\mathrm{R}^{2}=0.6123\right)$. Amino acids plotted were leucine, lysine, threonine, isoleucine, valine, and phenylalanine each at 2 doses. Data from MacRae et al. (1997b)

Fig. 12.5. Absorption of short-chain fatty acids (SCFA) in the portal vein as a function of Digestible energy intake. (a) sheep: $y=0.455 x-0.7642\left(R^{2}=0.496\right)$. (b) cattle $y=0.4626 x-3.0855$ $\left(\mathrm{R}^{2}=0.954\right)$. Data are taken from (a) sheep: Patil et al. (1995); Goetsch and Ferrell (1995); Goetsch et al. (1994); Gross et al. (1990); Rémond et al. (1993); Freetly and Ferrell (1998); Han et al. (2002) (b) cattle: Benson et al. (2002); Casse et al. (1994); Caton et al. (2001); Gross et al. (1988); Huntington et al. (1988; 1996); Lozano et al. (2000); Maltby et al. (1993); Reynolds et al. (1988 a; 1992 b, c; 1993 a, b; 1994 b; 1995; 1998 a, b; 1999; 2000; 2001; 2003 a, b); Reynolds (unpublished); Taniguchi et al. (1995)

Fig. 12.6. Relation between the sum of glycogenic (propionate, isobutyrate, lactate) and ketogenic (acetate, butyrate, 3-hydroxybutyrate) short chain fatty acids released from the portal vein. (a) sheep $y=0.5398-0.0085\left(R^{2}=0.904\right)(b)$ cattle. $y=0.4815+3.97\left(R^{2}=0.863\right)$. Data taken from the same sources as Fig. 12.5

Fig. 12.7. (a) Glucose released by cattle liver, as a function of the digestible energy Intake $\mathrm{y}=2.6912 \mathrm{x}-3.0651\left(\mathrm{R}^{2}=0.952\right)(\mathrm{b})$ Glucose released in relation to propionate taken up by cattle liver. $\mathrm{y}=0.6999 \mathrm{x}+65.294\left(\mathrm{R}^{2}=0.914\right)$ Data are taken from the same sources as Fig. 12.5 and Fig. 12.6.

Fig. 12.8. (a) 3-hydroxy butyrate release from cattle liver as a function of butyrate removal. $\mathrm{y}=2.0122 \mathrm{x}+19.277\left(\mathrm{R}^{2}=0.725\right)(\mathrm{b})$ Release of $\mathrm{C} 2$ units (as acetate and 3-hydroxybutyrate, related to removal of free fatty acids, butyrate and acetoacetate. $y=1.645 x-3.4298\left(R^{2}=0.964\right)$ Data taken from: Casse et al. (1994); Caton et al. (2001); Huntington et al. (1996); Krehbiel et al. (1992); Lozano et al., (2000); Reynolds and Tyrrell (1991); Reynolds et al. (1988 a; 1992 b; 1994 
b; 2003 a); Taniguchi et al. (1995)

Fig. 12.9. Nitrogen metabolism in cattle. (a) Ammonia absorbed in the portal vein as a function of dietary Nitrogen intake $y=0.4059 x+17.146\left(R^{2}=0.917\right)(b)$ Alpha amino nitrogen absorbed in the portal vein as a function of dietary Nitrogen intake $y=0.3076 \mathrm{x}-2.5268\left(\mathrm{R}^{2}=0.871\right)(\mathrm{c})$ Alpha amino nitrogen absorbed in the portal vein as a function of Digestible energy intake $y=0.6755 \mathrm{x}-$ $14.379\left(\mathrm{R}^{2}=0.904\right)$ (d) Ammonia removal by liver in relation to urea release $\mathrm{y}=0.5426 \mathrm{x}+26.382$ $\left(\mathrm{R}^{2}=0.815\right)$. Data derived from Alio et al. (2000); Blouin et al. (2002); Bruckental et al. (1997); Casse et al. (1994); Caton et al. (2001); Gross et al. (1988); Huntington et al. (1988; 1996); Maltby et al. (1993); Lapierre et al. (2000); Reynolds (unpublished); Reynolds and Tyrrell (1991); Reynolds et al. (1988b; 1991c; 1992 a, b, c; 1995; 1998 a, b; 1999; 2000; 2001; 2003 a, b); Taniguchi et al. (1995) 